\title{
Erratum to: Determination of manganese in iron and iron concentrates by parametric methods of neutron activation analysis, using ${ }^{59} \mathrm{Fe}$ as internal monitor
}

\author{
Isaac M. Cohen ${ }^{1} \cdot$ María Sol Segovia $^{1} \cdot$ Sandra Siri $^{2}$
}

Published online: 20 July 2016

(C) Akadémiai Kiadó, Budapest, Hungary 2016

Erratum to: J Radioanal Nucl Chem (2016)

\section{9:53-57}

DOI 10.1007/s10967-016-4788-3

In the original publication of an article, first author's name was misspelt. The correct name is given in this erratum.

The online version of the original article can be found under doi:10.1007/s10967-016-4788-3.

Isaac M. Cohen

marcos_cohen@yahoo.com; mcohen@frba.utn.edu.ar

1 Departamento de Ingeniería Química, Facultad Regional

Buenos Aires, and Grupo IDETQA, Universidad

Tecnológica Nacional, Medrano 951,

C1179AAQ Ciudad Autónoma de Buenos Aires,

República Argentina

2 Comisión Nacional de Energía Atómica, Centro Atómico

Ezeiza, Presbítero González y Aragón 15,

B1802AYA Buenos Aires, República Argentina 